\title{
Evaluation of the Pichia pastoris expression system for the production of GPCRs for structural analysis
}

\author{
Hidetsugu Asada ${ }^{1,2}$, Tomoko Uemura', Takami Yurugi-Kobayashi, ${ }^{1,2}$, Mitsunori Shiroishi ${ }^{1}$, Tatsuro Shimamura ${ }^{1,2}$, \\ Hirokazu Tsujimoto ${ }^{1}$, Keisuke Ito ${ }^{3}$, Taishi Sugawara ${ }^{3}$, Takanori Nakane ${ }^{2}$, Norimichi Nomura ${ }^{1,2}$, Takeshi Murata', \\ Tatsuya Haga ${ }^{4}$, So Iwata ${ }^{1,2,5,6^{*}}$ and Takuya Kobayashi ${ }^{1,2,5^{*}}$
}

\begin{abstract}
Background: Various protein expression systems, such as Escherichia coli (E. coli), Saccharomyces cerevisiae (S. cerevisiae), Pichia pastoris (P. pastoris), insect cells and mammalian cell lines, have been developed for the synthesis of $\mathrm{G}$ protein-coupled receptors (GPCRs) for structural studies. Recently, the crystal structures of four recombinant human GPCRs, namely $\beta_{2}$ adrenergic receptor, adenosine $A_{2 a}$ receptor, CXCR4 and dopamine D3 receptor, were successfully determined using an insect cell expression system. GPCRs expressed in insect cells are believed to undergo mammalian-like posttranscriptional modifications and have similar functional properties than in mammals. Crystal structures of GPCRs have not yet been solved using yeast expression systems. In the present study, P. pastoris and insect cell expression systems for the human muscarinic acetylcholine receptor M2 subtype (CHRM2) were developed and the quantity and quality of CHRM2 synthesized by both expression systems were compared for the application in structural studies.

Results: The ideal conditions for the expression of CHRM2 in P. pastoris were $60 \mathrm{hr}$ at $20^{\circ} \mathrm{C}$ in a buffer of $\mathrm{pH} 7.0$. The specific activity of the expressed CHRM2 was $28.9 \mathrm{pmol} / \mathrm{mg}$ of membrane protein as determined by binding assays using $\left[{ }^{3} \mathrm{H}\right]$-quinuclidinyl benzilate (QNB). Although the specific activity of the protein produced by P. pastoris was lower than that of Sf9 insect cells, CHRM2 yield in P. pastoris was 2-fold higher than in Sf9 insect cells because P. pastoris was cultured at high cell density. The dissociation constant (Kd) for QNB in P. pastoris was $101.14 \pm 15.07$ $\mathrm{pM}$, which was similar to that in Sf9 insect cells $(86.23 \pm 8.57 \mathrm{pM})$. There were no differences in the binding affinity of CHRM2 for QNB between P. pastoris and Sf9 insect cells.
\end{abstract}

Conclusion: Compared to insect cells, P. pastoris is easier to handle, can be grown at lower cost, and can be expressed quicker at a large scale. Yeast, P. pastoris, and insect cells are all effective expression systems for GPCRs. The results of the present study strongly suggested that protein expression in P. pastoris can be applied to the structural and biochemical studies of GPCRs.

\section{Background}

G protein-coupled receptors (GPCRs) belong to the largest superfamily of cell surface receptors. The GPCRs are integral transmembrane proteins and mediate various cellular responses to specific functional ligands including amine, eicosanoid, hormone and peptide, as

\footnotetext{
*Correspondence: s.iwata@mfour.med.kyoto-u.ac.jp; t-coba@mfour.med. kyoto-u.ac.jp

'Iwata Human Receptor Crystallography project, ERATO, JST, Konoe-cho, Yoshida, Sakyo-ku, Kyoto 606-8501, Japan

Full list of author information is available at the end of the article
}

well as taste and light stimuli. Approximately $50 \%$ of all currently available drugs act through GPCRs [1,2]. GPCRs are among the most important therapeutic targets for various disorders. Structure guided drug development is therefore important for the design of novel drugs devoid of side effects.

The crystal structure of membrane proteins such as GPCRs is difficult to solve due to several technical bottlenecks. One of the main obstacles for the resolution of crystal structures is the preparation of sufficiently large amounts of functional GPCR protein [3]. Milligram

\section{Biomed Central}


quantities of purified protein are required for crystallization and structural determination. Bovine rhodopsin [4], bovine opsin [5] and squid rhodopsin [6,7], whose crystal structures have been solved, are expressed in large amounts endogenously, and therefore can be obtained from natural sources, whereas other GPCRs cannot be purified in large amounts from natural tissues because of their low endogenous expression levels. In addition to insect cells [8-16], various expression systems can be applied to obtain a high yield of GPCRs, such as Escherichia coli [17-21], Saccharomyces cerevisiae [22,23], Pichia pastoris [24-30], mammalian cell lines [31-33], and a cell-free translation system [34-39]. We previously identified 25 GPCRs expressed by $P$. pastoris [29], which led us to suggest that $P$. pastoris is a suitable host for GPCR crystal structural studies. However, the crystal structures of recombinant human $\beta_{2}$-adrenergic receptor (ADRB2) [40,41], human adenosine $\mathrm{A}_{2 \mathrm{~A}}$ receptor (ADORA2A) [42], human CXCR4 chemokine receptor [43], human dopamine D3 receptor [44] and turkey $\beta_{1}$ adrenergic receptor (ADRB1) [13] have been determined successfully using only insect cells, in the present study, the quality and quantity of GPCRs expressed in P. pastoris were compared directly with those from Sf9 insect cells. Together with our previous study, the results show clearly that the P. pastoris expression system is an efficient system for GPCR production.

The muscarinic acetylcholine receptor (CHRM) belongs to the GPCR superfamily and plays important roles in signal transduction in the central and peripheral nervous systems $[45,46]$. The muscarinic actions of acetylcholine in central and peripheral physiological and pathophysiological processes are mediated by five molecularly distinct CHRMs labeled 1-5 [47-51]. One of the structural properties of all CHRM subtypes is a long third intracellular loop (i3) composed of about 160-240 amino acid residues. Prior studies have attempted to express human CHRM2 with a deletion in the central part of the third intracellular loop from Ser234 to Arg381 using various expression systems, including E. coli $[17,18]$, P. pastoris [29], and insect cells [52].

The present study focuses on the potential of P. pastoris to express GPCR proteins that are adequate for structural analysis. The X-ray crystal structures of several membrane proteins, including the mammalian potassium channel [53] and the molluscan acetylcholine-binding protein [54], were successfully solved using the $P$. pastoris expression system. Insect cell-based expression systems have certain disadvantages for protein expression compared to $P$. pastoris, such as more involved and costlier culture requirements, as well as the difficulty in developing large-scale fermentation systems. Furthermore, the preparation of sufficient amounts of baculovirus for large-scale expression is time consuming. $P$. pastoris expression systems, on the other hand, are easily controlled for the optimization of growth conditions for the induction of the receptor of interest, including culture scale, temperature, time and $\mathrm{pH}$ value. In the present study, the quality and quantity of CHRM2 protein produced from $P$. pastoris and insect cells were compared for their potential use in structural studies of GPCRs.

\section{Results}

Comparison between culture conditions in P. pastoris and Sf9 insect cells during receptor overexpression

In the crystal structure determination of turkey ADRB1, human ADRB2, and human ADORA2A, all three GPCRs were produced as recombinant proteins in Sf9 or High-5 insect cells. However, the yeast $P$. pastoris can grow rapidly, can reach high cell densities, and it contains the necessary elements to perform posttranslational modifications that might be essential for protein function. The use of a tightly regulated strong promoter, alcohol oxidase 1 (AOX1), which is inducible by methanol as the sole carbon source, enables the production of a large amount of recombinant GPCRs in P. pastoris. Figure 1A shows the temporal differences between GPCR expression using $P$. pastoris or Sf9 insect cells from expression vector construction to large-scale expression. The total time to large-scale expression was about 24-28 days in P. pastoris compared to about 4045 days in Sf9 insect cells, with a temporal difference of 17-21 days between the systems. Thus, the P. pastoris expression system required less time to generate suitable clones for various GPCRs for crystal structural study. Figure $1 \mathrm{~B}$ shows the construction of recombinant CHRM2 as a model protein for structural analysis using 2 expression systems.

Culture conditions such as cell density, nutrient metabolism and $\mathrm{pH}$, which contribute to optimal recombinant protein production, were compared between $P$. pastoris and insect cells. $P$. pastoris transformants were inoculated and grown in BMGY medium, in which glycerol was the sole carbon source, overnight or until an $\mathrm{OD}_{600}$ of 2-6 was reached. The cells were then harvested by centrifugation. To induce expression of the protein of interest by methanol, the cell pellet was resuspended to an $\mathrm{OD}_{600}$ of 1.0 , corresponding to $5 \times$ $10^{7}$ cells $/ \mathrm{ml}$ in BMMY medium (0.5\% methanol). The cell density increased up to $2.4 \pm 0.3 \times 10^{9} \mathrm{cells} / \mathrm{ml}$ in the baffled shake flask until 3 days after methanol induction of the recombinant protein (Figure 2A). Methanol was added to a final concentration of $1 \%$ every $24 \mathrm{hr}$ during the induction phase, maintaining the total concentration between $0.5 \%$ and $1.5 \%$ to minimize toxicity (Figure $2 \mathrm{~B}$ ). The $\mathrm{pH}$ in the induction medium 


\section{A}
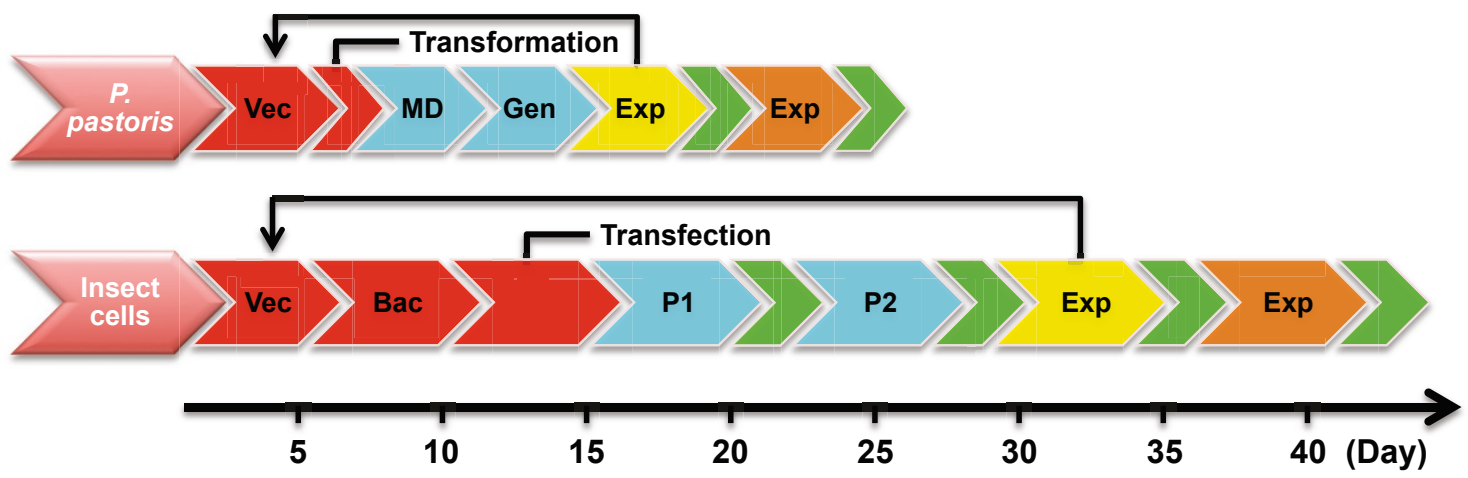

B

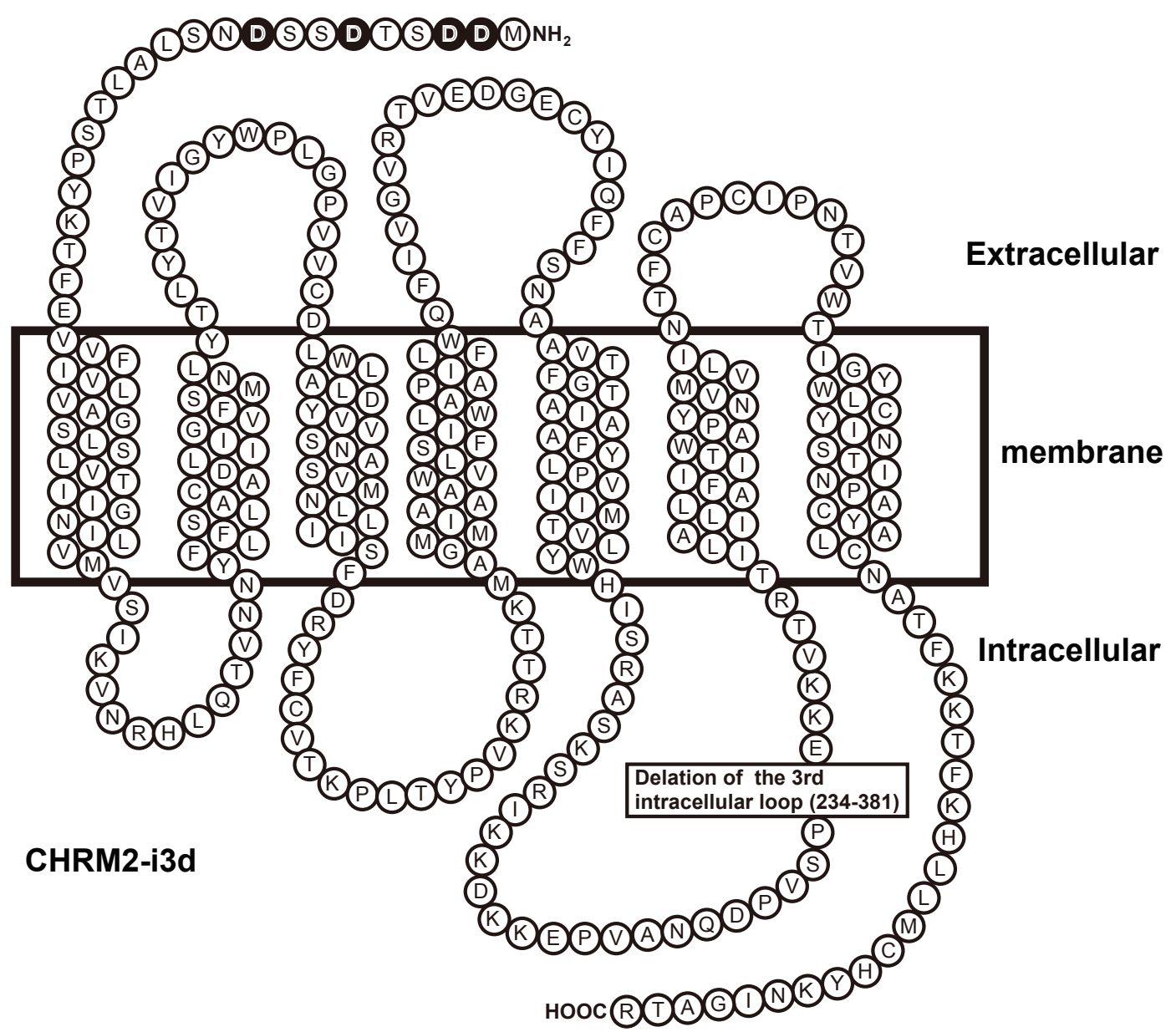

Figure 1 Schema of GPCR expression in P. pastoris and Sf9 insect cells and human CHRM2 mutant. The CHRM2-expressing plasmid vector was constructed (Vac.). In the P. pastoris expression system, the plasmid was transformed into the P. pastoris strain SMD1163. The transformants were inoculated onto MD plates (MD) and selected by YPD agar plates containing G418 (0.1 or $0.25 \mathrm{mg} / \mathrm{mL})(\mathrm{Gen})$. In the Sf9 insect cell expression system, baculovirus was obtained by homologous recombination in E. coli using the Bac-to-Bac baculovirus expression system (Invitrogen) (Bac.). Baculoviruses were amplified stepwise (P1 and P2). Small- and large-scale cultures are shown in yellow and orange, respectively. Evaluation by a ligand-binding assay is represented in green (A). Four N-linked glycosylation sites in the N-terminus were eliminated by converting asparagine residues (Asn2, 3, 6 and 9) to aspartic acid (Asp). Amino acid residues 234- 381 of the third intracellular loop of the human CHRM2 were deleted (B). 
D

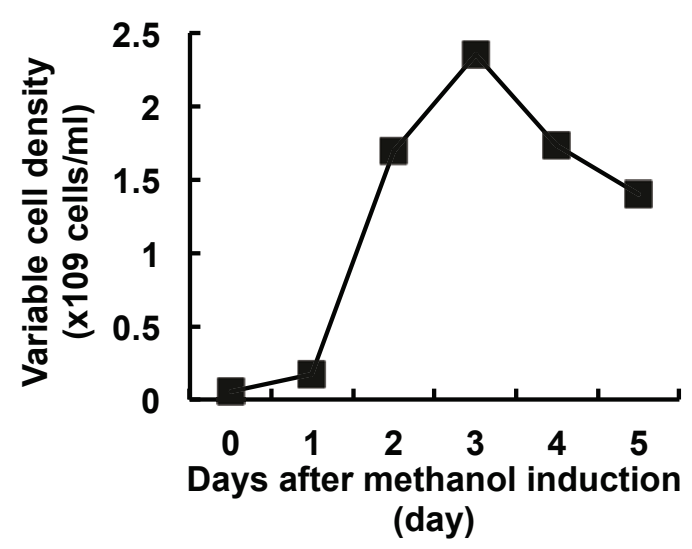

B

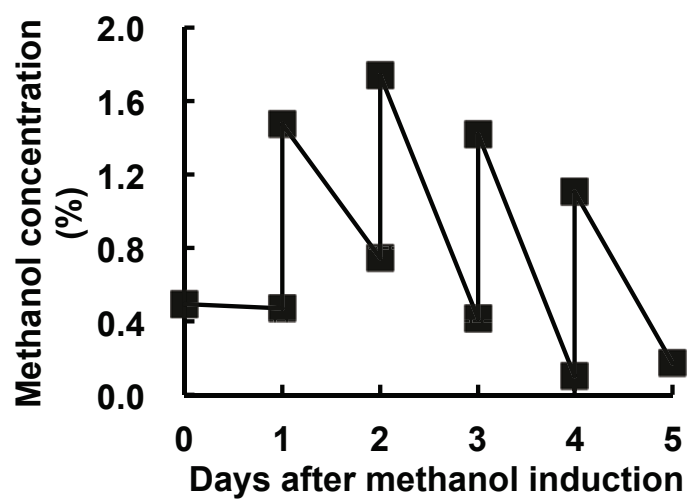

(day)

C

$\mathbf{F}$

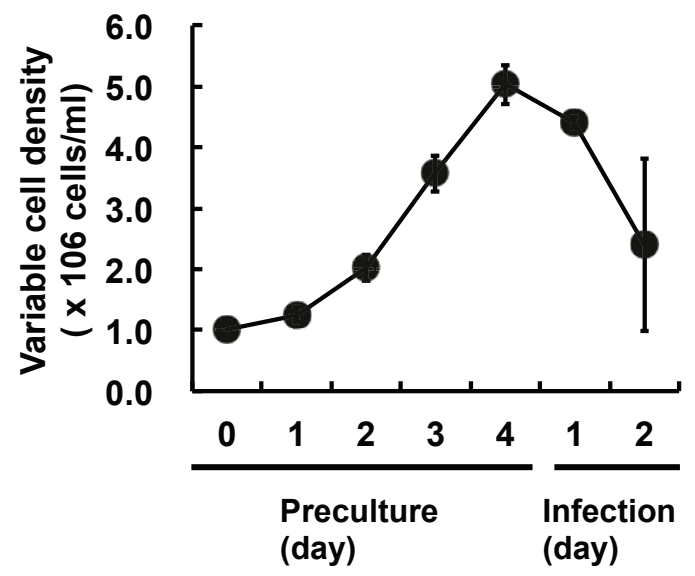

E
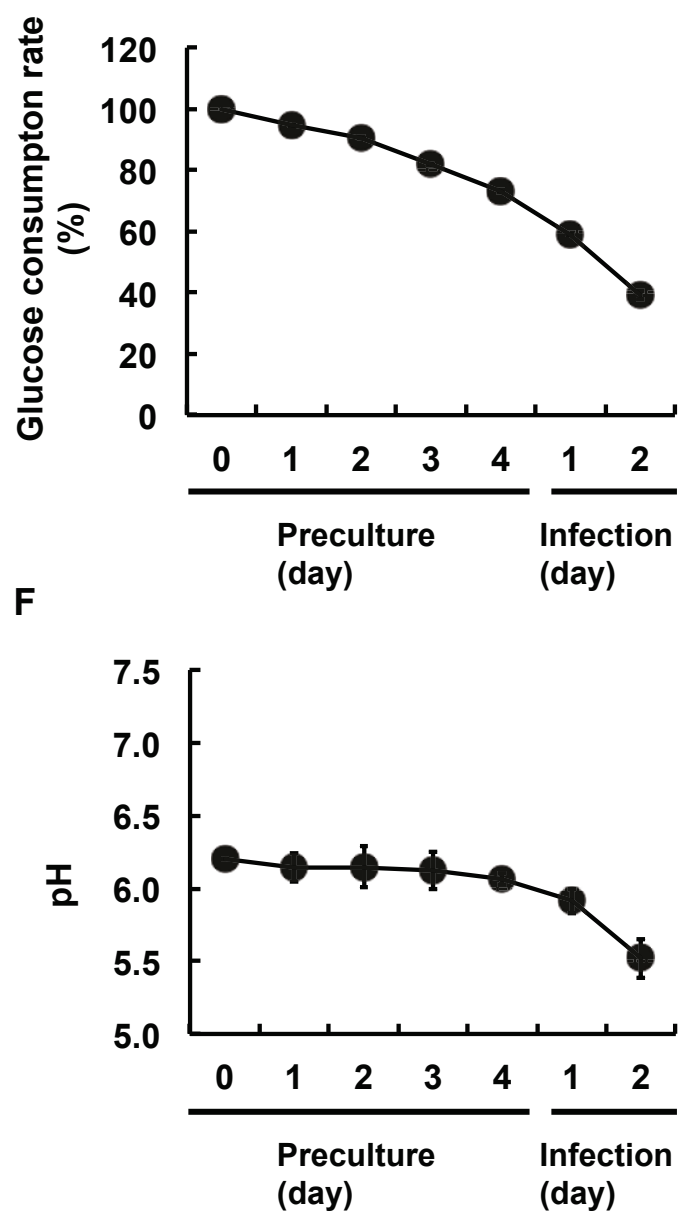

Figure 2 Comparison of culture conditions in P. pastoris and Sf9 insect cells. In P. pastoris, cell density (A), methanol concentration (B), and $\mathrm{pH}(\mathrm{C})$ were measured until 5 days after methanol induction. Cell density was estimated from OD 600 . Methanol concentration was monitored before and after methanol addition using a methanol sensor system (RAVEN Biotech Inc.). In Sf9 insect cells, cell density (D), glucose concentration (E), and pH (F) were measured during the period from preculture (4 days) to baculovirus infection (2 days). Cells were stained with $0.25 \%$ trypan blue in PBS (-) and living cells were counted with a hemocytometer. 
gradually decreased, requiring 5 days for a reduction from 7.0 to $6.5 \pm 0.2$ (Figure $2 \mathrm{C}$ ).

For the generation of baculovirus-infected Sf9 insect cells, baculovirus was added at a multiplicity of infections (MOI) of 2 when insect cells reached $5.0 \pm 0.3 \times$ $10^{6}$ cells $/ \mathrm{ml}$, showing a viability greater than $95 \%$ in the cellbag using the Wave Bioreactor system. A period of 4 days was necessary to achieve the desired cell density from the seeding at $1.0 \times 10^{6}$ cells $/ \mathrm{ml}$. In contrast to the viability of $P$. pastoris during the production of recombinant CHRM2, Sf9 cell density decreased progressively after the baculovirus infection (Figure 2D). Glucose content decreased in a time-dependent manner (Figure 2E) and the $\mathrm{pH}$ in the culture medium remained constant at approximately 6.4 during the 4 preculture days, but rapidly decreased from 6.1 to $5.5 \pm 0.1$ in the 2 days after baculovirus infection (Figure 2F). The diameter of the Sf9 insect cells, which can be used as an indicator of viral infection, increased by $>1 \mu \mathrm{m}$ after 2 days of viral infection compared with uninfected Sf9 insect cells (see Fig. S1 in additional file 1).

\section{Optimization of CHRM2 expression parameters in P.} pastoris

The optimization of expression conditions, including induction time, temperature and $\mathrm{pH}$, can be controlled in small-scale $P$. pastoris cultures during methanol induction for the production of the highest levels of the protein of interest. Whereas the scaling-up of the culture system in Sf9 insect cells decreased the production of CHRM2 (data not shown), the expression levels of CHRM2 in P. pastoris increased in correlation with the scale-up of the cell culture [29]. Specific binding of $\left[{ }^{3} \mathrm{H}\right]$ QNB continued to increase up to $60 \mathrm{hr}$ at $20^{\circ} \mathrm{C}$ in $\mathrm{pH}$ 6.0, 7.0 and 8.0 (Figure 3A, B and $3 \mathrm{C}$ ). The expression levels of CHRM2 at $30^{\circ} \mathrm{C}$ were lower than those at $20^{\circ} \mathrm{C}$

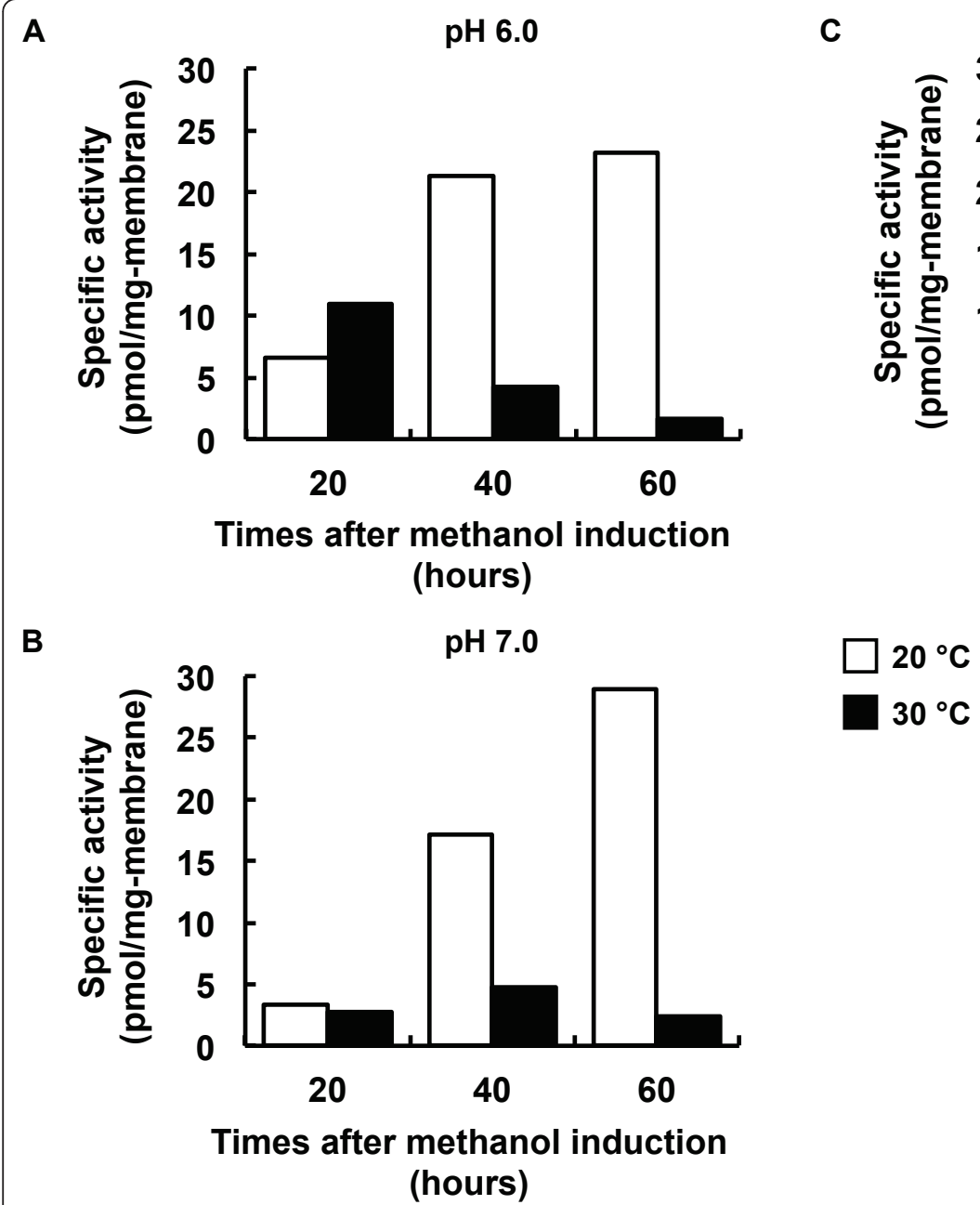

Figure 3 Optimization of $\boldsymbol{P}$. pastoris culture conditions. . pastoris was cultured in various conditions and the expression levels of $\mathrm{CHRM} 2$ were estimated by specific ligand binding assay. To find the optimal growth conditions, the pH of the medium at 6.0 ( $A$ ), 7.0 (B) and 8.0 (C), the induction temperature $\left(20\right.$ or $\left.30^{\circ} \mathrm{C}\right)$, and expression times $(20,40$ and $60 \mathrm{hr}$ ) were evaluated in all possible combinations. 
under most conditions (Figure 3A, B and $3 \mathrm{C}$ ). The $\mathrm{pH}$ of the culture medium did not affect the expression levels. The highest specific activity $(28.9 \mathrm{pmol} / \mathrm{mg}$ of membrane protein) was obtained under optimized conditions $\left(60 \mathrm{hr}, \mathrm{pH} 7.0,20^{\circ} \mathrm{C}\right)$.

\section{Quantity and quality of CHRM2 expressed in P. Pastoris and Sf9 insect cells}

The preparation of large quantities of CHRM2 possessing the appropriate ligand binding activity or affinity is necessary for structural studies. A comparison of the quality and quantity of CHRM2 expressed through large scale cultures of $P$. pastoris and Sf9 insect cells was performed by competition binding assays with $\left[{ }^{3} \mathrm{H}\right] \mathrm{QNB}$ (Figure 4). A maximum specific activity was reached at $17.2 \pm 1.0 \mathrm{pmol} / \mathrm{mg}$ of membrane in P. pastoris on day 3 after methanol induction and the high expression level was maintained until day 4 (Figure $4 \mathrm{~A}$ ). In contrast, the maximum specific activity of CHRM2 in Sf9 insect cells was obtained at $23.2 \pm 8.0 \mathrm{pmol} / \mathrm{mg}$ of membrane on day 2 after baculovirus infection, followed by a progressive decrease (Figure 4A). The amount of CHRM2 expressed in $P$. pastoris gradually increased up to day 3 (Figure 4B). A total of $4 \mathrm{mg}$ of CHRM2 was expressed from 5 L-culture medium on day 3. In Sf9 insect cells, $2.3 \pm 1.1 \mathrm{mg}$ of CHRM2 was the maximum amount expressed from 5 L-culture medium on day 2, which then decreased to approximately $1 \mathrm{mg} / 5 \mathrm{~L}$-culture. Based on their maximum expression levels, CHRM2 was expressed at an almost 2-fold higher level in $P$. pastoris than in Sf9 insect cells per 5 L-culture medium (Figure 4B). High cell density in P. pastoris enabled the production of higher quantities of CHRM2 compared to the amounts produced in $\mathrm{Sf} 9$ insect cells.

To compare the quality of the CHRM2 expressed in $P$. pastoris to that produced in Sf9 insect cells, the $\mathrm{Kd}$

\section{A}

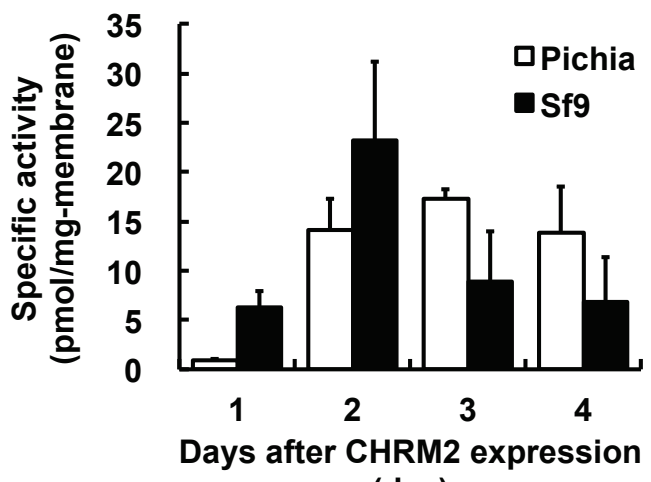

(day)

B

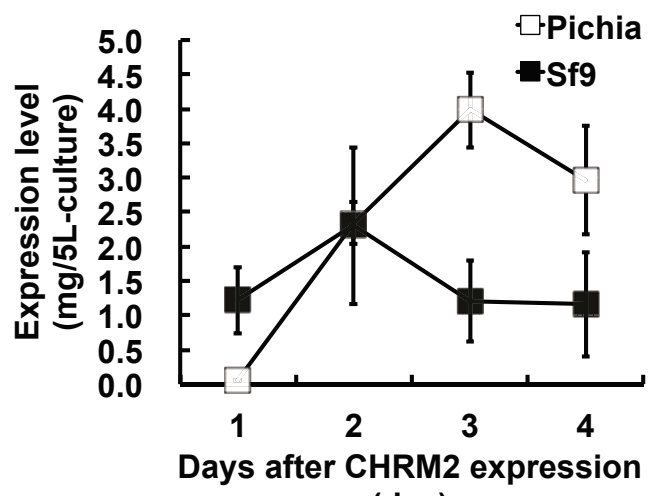

(day)
C

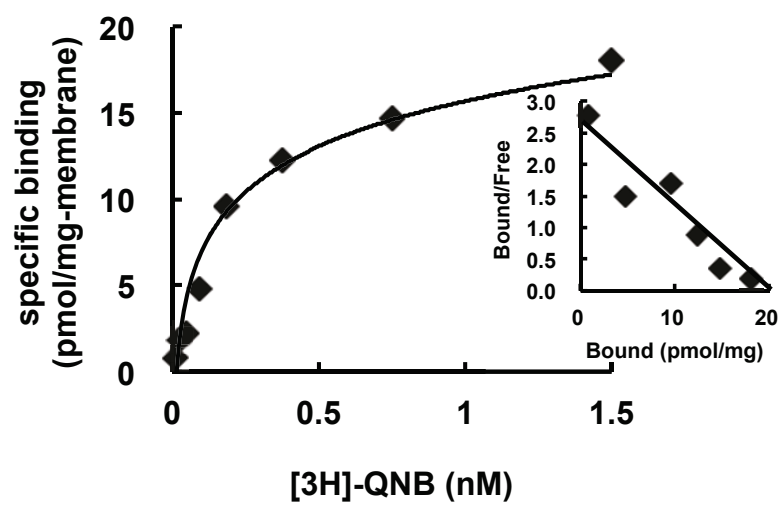

D

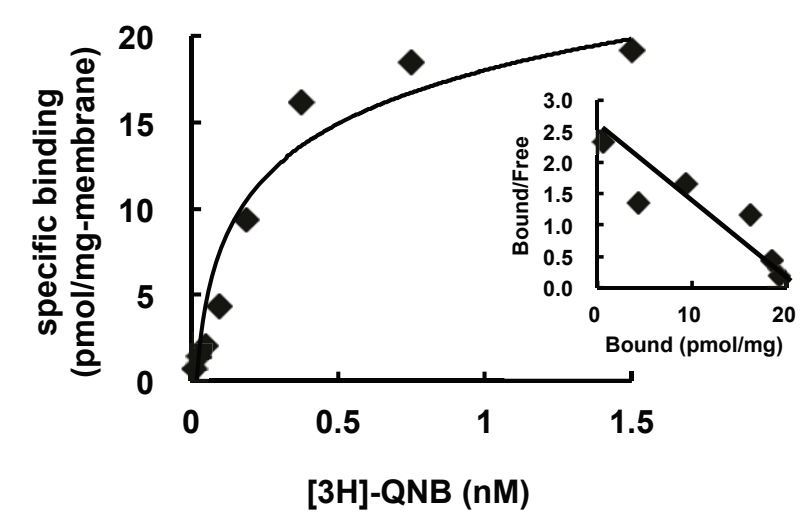

Figure 4 Functional comparison of $P$. pastoris and Sf9 insect cell expression systems. The specific activities of CHRM2 from $P$. pastoris and Sf9 insect cells are shown (A). CHRM2 expression was induced by the addition of methanol in P. pastoris and by the infection of baculovirus in Sf9 insect cells. The total CHRM2 protein (mg) expressed from 5 L-cultures of P. pastoris and Sf9 insect cells was assessed by a specific ligand binding assay (B). To compare the quality of CHRM2 from P. pastoris (C) and Sf9 insect cells (D), biochemical properties were evaluated by Kd and Bmax values from saturation curves and scattered plots. 
values for the binding of $\left[{ }^{3} \mathrm{H}\right] \mathrm{QNB}$ to CHRM2 in both expression systems were calculated from Scatchard plots of the saturation binding experiments (Figure $4 \mathrm{C}$ and 4D). A representative figure of the saturation binding assay and the Scatchard plot from P. pastoris are shown in Figure 4C. The Bmax value was $33.5 \pm 7.08 \mathrm{pmol} / \mathrm{mg}$ of membrane protein and the Kd value was 101.14 \pm $15.07 \mathrm{pM}$. A representative figure of the saturation binding assay and the Scatchard plot from Sf9 insect cells are shown in Figure 4D. The Bmax value was $27.17 \pm$ $5.57 \mathrm{pmol} / \mathrm{mg}$-membrane and the $\mathrm{Kd}$ value was $86.23 \pm$ $8.57 \mathrm{pM}$. These results indicated that the CHRM2 obtained from both expression systems had a nearly identical quality.

\section{Solubilization and purification of CHRM2 expressed in P. Pastoris}

In a GPCR structural study, it is important to determine whether the GPCRs are able to be solubilized and purified. Therefore, we attempted the solubilization and purification of CHRM2 from P. pastoris (Figure 5). The purity of CHRM2 from $P$. pastoris progressively increased with each purification step. The specific activity of CHRM2 after ConA flow-through reached $>2000$ $\mathrm{pmol} / \mathrm{mg}$ of protein, and was approximately 100 times higher than that of CHRM2 in the membrane (Figure 5A). CHRM2 purified by TALON metal affinity resin appeared as dimerized CHRM2, and impurities were identified in the SDS-PAGE and Coomassie Brilliant Blue (CBB) stain (Figure 5B). However, after ConA agarose purification, CHRM2 was well purified and observed as a single monomer band. These results showed that CHRM2 from $P$. pastoris could be solubilized and purified to the same extent as protein from $\mathrm{Sf} 9$ insect cells [52]. Impurities were removed at every purification step; however, purification with ConA agarose particularly removed a large amount of impurities (Figure 5B).

\section{Comparison of other GPCRs expressed in P. Pastoris and Sf9 insect cells}

To show that many GPCRs can be isolated successfully from $P$. pastoris for crystal structural analysis, we investigated the specific binding activities of 5 mammalian GPCRs expressed in P. pastoris and Sf9 insect cells (Table 1). Human ADORA2A, tachykinin receptor 2 (TACR2), dopamine receptor D2 (DRD2), angiotensin receptor type 2 (AGTR2), and rat TACR2 were expressed in $P$. pastoris and Sf9 insect cells similar to CHRM2. Each GPCR was subjected to a binding assay using radioisotope-labeled specific ligands.

For ADORA2A, the specific activity was extremely high ( $>200 \mathrm{pmol} / \mathrm{mg}$ of membrane) compared with the other GPCRs. However, there was no difference in activity between ADORA2A expressed in P. pastoris or Sf9 insect cells. For human and rat TACR2, the specific activities for GPCRs expressed in P. pastoris were 2.56.5 times higher than those expressed in Sf9 insect cells. The specific activities of human DRD2 and AGTR2 from $P$. pastoris were 1.3-2.2 times higher than those expressed in Sf9 insect cells. These results suggest that P. pastoris is a suitable host for GPCR structural studies comparable to Sf9 insect cells.

\section{Discussion}

Insect cells such as Sf9 and High5 are the preferred expression hosts for the determination of the crystal structure of GPCRs [40-42,55]. However, the use of $P$. pastoris as a host system for the expression of GPCRs offers several advantages. P. pastoris is capable of expressing heterologous genes at high levels under the control of the strong and tightly regulated AOX1 promoter, and has already been used as an effective host for the X-ray crystallographic studies of the Kv channel $[53,56,57]$. This methylotrophic yeast combines several advantages of both prokaryotic and animal cell expression systems. It is readily amenable to genetic manipulation, it can be easily grown to high cell densities using minimal media, and it possesses the necessary elements to introduce eukaryotic posttranslational modifications. The present study compared Sf9 insect cells and P. pastoris as expression systems for the production of GPCRs for crystallization and structural analysis. As shown in Figure 2, culture conditions including cell density, nutrient metabolism and $\mathrm{pH}$ were monitored during the production of CHRM2 as a model protein in Sf9 insect cells and $P$. pastoris.

The cell density of $P$. pastoris increased up to day 3 during methanol induction, and then began to decrease as the culture was starved of dissolved oxygen $\left(\mathrm{dO}_{2}\right)$ and nutrients (Figure 2A). As a result, the concentration of P. pastoris-expressed CHRM2 was highest on day 3 after methanol induction (Figure 4B). On the other hand, the highest expression level in Sf9 insect cells, which was obtained on day $2(2.0 \mathrm{mg} / 5 \mathrm{~L}$-culture), amounted to one half of the maximum expression in P. pastoris ( $4.0 \mathrm{mg} / 5 \mathrm{~L}$-culture) (Figure $4 \mathrm{~B})$. The viability of insect cells decreased by $50 \%$ in two days after baculovirus infection (Figure 2D), whereas the cell density in $P$. pastoris increased until the maximum expression level was reached on day 3 (Figure 2A). Western blotting to detect CHRM2 revealed significant proteolytic degradation of the expressed protein in Sf9 insect cells [58]. Proteolytic degradation in virus-infected insect cells can be attributed to the action of carboxyl and cysteine proteases [59]. Addition of aprotinin and pepstatin A, which are inhibitors of carboxyl and cysteine proteases, respectively, to a virus-infected insect cell culture increased the yield of the infectious bursal disease 


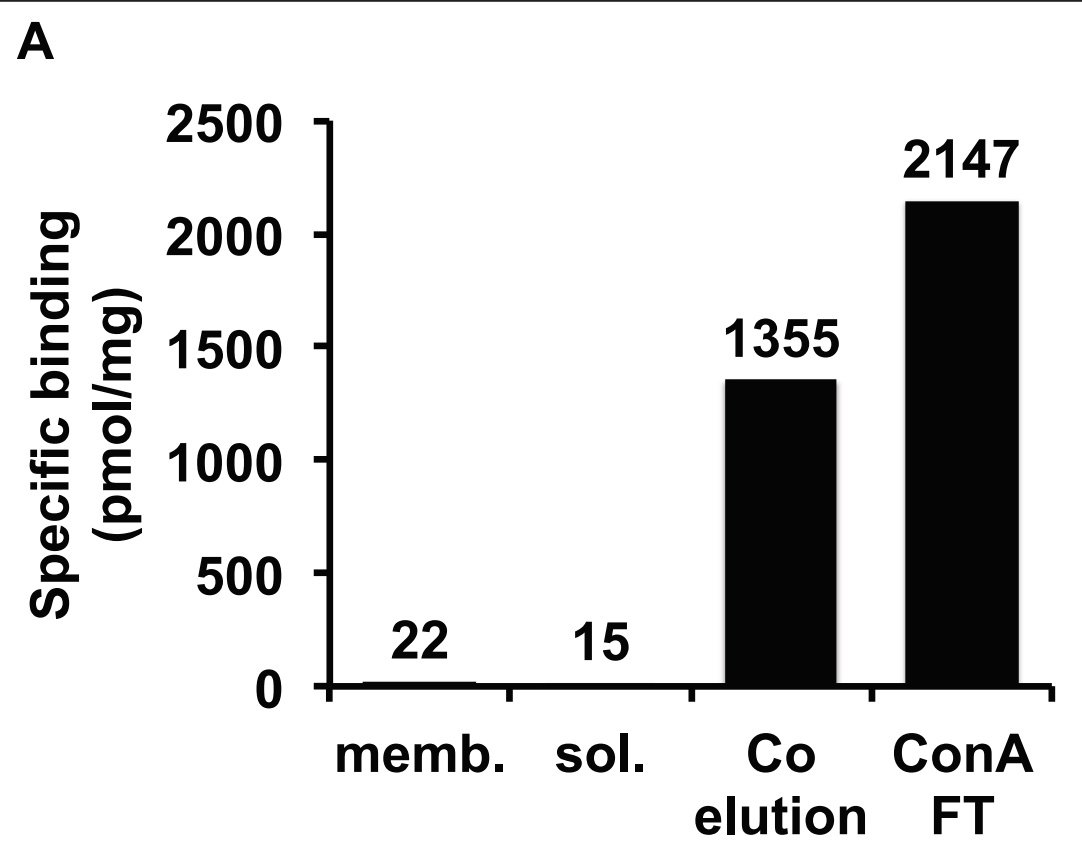

B

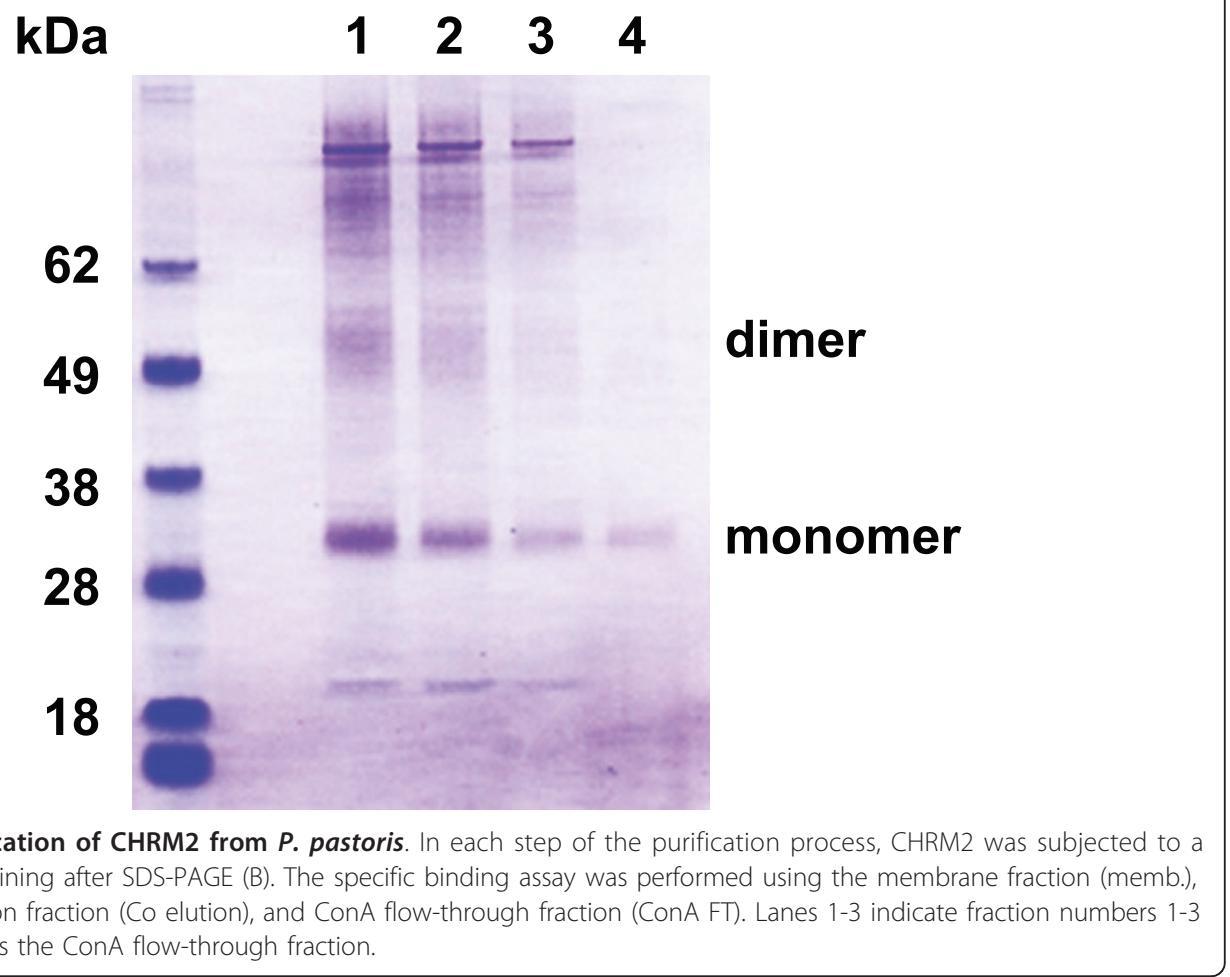


Table 1 Comparison of the specific binding activity in other GPCRs expressed from P. pastoris and Sf9 insect cells system

\begin{tabular}{llll}
\hline GPCR & P. pastoris & Sf9 & Ligand \\
\hline hADORA2A & $220.81 \pm 17.05$ & $239.23 \pm 47.12$ & ZM241385 $^{\text {a) }}$ \\
hTACR2 & $61.96 \pm 9.83$ & $9.41 \pm 2.46$ & SR48968 $^{\text {a) }}$ \\
hDRD2 & $7.75 \pm 1.54$ & $5.98 \pm 1.17$ & Spiperone $^{\text {a) }}$ \\
hAGTR2 & $3.69 \pm 0.42$ & $1.66 \pm 0.08$ & Angiotenin $^{\text {b) }}$ \\
rTACR2 & $36.60 \pm 12.99$ & $14.2 \pm 5.41$ & SR48968 $^{\text {a) }}$
\end{tabular}

All GPCRs were expressed under small-scale culture conditions. Each membrane was prepared from cells, and the specific binding assay was determined using radioactive-labeled specific ligand respectively. hADORA2A human adenosine A2a receptor; hTACR2 and rTACR2, human and rat tachykinin receptor 2, respectively; hDRD2, human dopamine receptor D2; hAGTR2, human angiotensin receptor type 2 . a, antagonist; b, agonist. The data are presented as $\mathrm{pmol} / \mathrm{mg}$-membrane and mean \pm S.D. $(n=3$ each).

virus structural protein nearly 2 -fold [60]. The viability in a virus-infected cell culture might be associated with the yield of functional CHRM2 obtained in Sf9 insect cells. An expression level greater than $1 \mathrm{mg} / \mathrm{L}$-culture is the preferred level for purification and crystallization experiments. Warne et al. expressed more than $1 \mathrm{mg}$ of unpurified mutant turkey ADRB1 per liter of culture using the baculovirus system [13] and improved the expression level (numbers of functional receptors/mg of membrane) to $360 \mathrm{pmol} / \mathrm{mg}$ solubilized membrane protein, in addition to enhancing the total expression level. These results suggest that not only substantial quantities but also expression levels are critical factors for structural analysis.

To determine whether the recombinant CHRM2 expressed in P. pastoris and Sf9 insect cells was different in quality, a Scatchard analysis was performed from a saturation $\left[{ }^{3} \mathrm{H}\right] \mathrm{QNB}$ binding experiment to determine a dissociation constant $(\mathrm{Kd})$. The $\mathrm{Kd}$ values measured in the present study from $P$. pastoris $(101.14 \pm 15.07 \mathrm{pM})$ and Sf9 insect cells $(86.23 \pm 8.57 \mathrm{pM})$ were comparable to those reported by previous studies. A Kd value of 25.7 $\mathrm{pM}$ and a Bmax value of $5.55 \mathrm{pmol} / \mathrm{mg}$ protein were reported for Sf9 insect cells [17]. A Kd value of $113.7 \mathrm{pM}$ and a Bmax value of $51.2 \mathrm{pmol} / \mathrm{mg}$ were reported for $P$. pastoris [29], suggesting the absence of significant differences in ligand binding activity between the two systems. The expression of cell surface molecules was monitored by flow cytometry to assess the production of properly folded proteins in the baculovirus expression system [61]. Cell surface expression of CHRM2 may result in differences between receptors produced in $P$. pastoris and Sf9 insect cells. However, surface expression, G-protein coupling and second messenger generation other than saturation ligand binding should be investigated to evaluate the sample grade for structural analysis.

As shown in Figure 3, the conditions used for the expression of CHRM2 in P. pastoris using a flask method were optimized based on a previously published method [29]. Flask cultures enable the application of several expression conditions in parallel and require limited equipment compared to bioreactor-based systems [27]. The addition of methanol to the $P$. pastoris culture every $24 \mathrm{hr}$ allows the control of the amount of nutrients added to the culture (Figure 2B). In the insect culture system, $35 \%$ of the glucose added as a nutrient to the cell culture medium had already been consumed at the time of baculovirus infection (Figure 2E). However, methanol concentration must be kept within a narrow range because excess formaldehyde produced by the oxidation of methanol by AOX1 can accumulate to cytotoxic levels [62]. The optimum pH range for stabilization and activity differs for each GPCR and should therefore be adjusted for each receptor during induction. The $P$. pastoris expression system enables the adjustment of $\mathrm{pH}$, as shown in Figure 3, which shows that there were no variations in $\mathrm{pH}$ values during the first three days after induction (Figure 2C).

It is important that GPCRs expressed from $P$. pastoris are evaluated for their solubilization and purification efficacy compared to proteins expressed from insect cells. The specific binding activities of CHRM2 and 5 other GPCRs expressed from P. pastoris and Sf9 insect cells were investigated (Figure 4 and Table 1 ). The specific activities of these GPCRs from $P$. pastoris were higher than those from Sf9 insect cells. Functional CHRM2 expressed from P. pastoris was solubilized and purified similar to CHRM2 expressed from Sf9 insect cells [52] (Figure 5).

Although previous studies have used $P$. pastoris as a GPCR expression host [24-29], to our knowledge this study is the first report to compare GPCRs expressed from $P$. pastoris directly with those expressed from Sf9 insect cells. The results of this study strongly suggest that many GPCRs, including CHRM2, can be expressed from $P$. pastoris with quality and quantity equal to those expressed from Sf9 insect cells. We think that GPCRs expressed from $P$. pastoris will be usable for crystal structural analysis.

\section{Conclusion}

The present study identified several advantages of $P$. pastoris over insect cells as an expression system for the production of GPCRs for structural studies. Compared to insect cells, the yield of CHRM2 expressed in $P$. pastoris was higher and the receptors produced by $P$. pastoris were also functional. The optimization of culture conditions, including $\mathrm{pH}$, induction time and temperature, was essential to obtain an adequate GPCR expression level in P. pastoris. Flask culture systems allow the optimization of several conditions in parallel, and the optimized conditions can be applied to bioreactor cultures, 
which yield higher cell densities than flask cultures [27]. The $P$. pastoris expression system is not only useful for functional and structural studies but also for the screening of more stable mutants with high expression levels, such as $\mathrm{N}$-terminal, C-terminal, and/or third intracellular loop truncation, replacement of the third intracellular loop by T4 lysozyme, $\mathrm{N}$-linked glycosylation deletion and other mutations.

\section{Methods \\ Materials}

The pPIC9K vector and P. pastoris strain SMD1163 were purchased from Invitrogen. Sf9 insect cells and recombinant CHRM2 baculovirus were prepared as described previously [52]. IPL-41 insect medium was purchased from AppliChem. ESF-921 insect medium was purchased from Expression Systems. SF900II insect medium, tryptose phosphate, TC extract, Pluronic F-68 and fetal bovine serum were purchased from Invitrogen. Penicillin-streptomycin mixture was purchased from Wako. $\left[{ }^{3} \mathrm{H}\right] \mathrm{QNB}$ (quinuclindinyl benzilate, $1.74 \mathrm{TBq} /$ $\mathrm{mmol}$ ) were obtained from GE Healthcare. Atropine was purchased from Sigma. GF/F glass fiber filters were purchased from Whatman and protease inhibitor cocktail tablets (Complete) were purchased from Roche Diagnostics.

\section{Construction of CHRM2 encoding vector for P. pastoris} CHRM2 cDNA was subcloned into the pPIC9K expression vector and linearized using the restriction enzyme PmeI. The linearized vector was transformed into the $P$. pastoris strain SMD1163 by electroporation (1500 V, 25 $\mu \mathrm{F}$, and $600 \Omega$ ) using a Gene Pulser I (Bio Rad). Clone selection was performed as previously described [63,64]. In brief, recombinant $\mathrm{His}^{+}$clones were selected on MD agar plates $(1.34 \%(\mathrm{w} / \mathrm{v})$ yeast nitrogen base without amino acids, $2 \%(\mathrm{w} / \mathrm{v})$ dextrose, $0.00004 \%(\mathrm{w} / \mathrm{v})$ biotin, and $1.5 \%(\mathrm{w} / \mathrm{v})$ agar). To select for multicopy transformants, $\mathrm{His}^{+}$clones were grown on G418-YPD agar plates $(1 \%(\mathrm{w} / \mathrm{v})$ yeast extract, $2 \%(\mathrm{w} / \mathrm{v})$ peptone, $2 \%(\mathrm{w} / \mathrm{v})$ dextrose, $2 \%(\mathrm{w} / \mathrm{v})$ agar, and 0.1 or $0.25 \mathrm{mg} / \mathrm{ml}$ G418). Representative clones exhibiting resistance to G418 were tested for recombinant protein production by specific ligand binding assays using $\left[{ }^{3} \mathrm{H}\right] \mathrm{QNB}$. The selected transformants were stored as glycerol stocks at $-80^{\circ} \mathrm{C}$.

\section{Small scale culture for $P$. pastoris}

Glycerol stocks of the transformants were inoculated onto YPD agar plates containing $0.1 \mathrm{mg} / \mathrm{ml}$ G418. For receptor production, cells were precultured in $5 \mathrm{ml}$ BMGY medium $(1 \%(\mathrm{w} / \mathrm{v})$ yeast extract, $2 \%(\mathrm{w} / \mathrm{v})$ peptone, $1.34 \%(\mathrm{w} / \mathrm{v})$ yeast nitrogen base without amino acids, $0.00004 \%(\mathrm{w} / \mathrm{v})$ biotin, 1\% (w/v) glycerol, and 0.1 M phosphate buffer at
$\mathrm{pH} 6.0)$ at $30^{\circ} \mathrm{C}$ with shaking at $250 \mathrm{rpm}$ until an $\mathrm{OD}_{600}$ of 2-6 was reached. Induction of CHRM2 expression was conducted in $5 \mathrm{ml}$ BMMY medium $(1 \%(\mathrm{w} / \mathrm{v})$ yeast extract, $2 \%(\mathrm{w} / \mathrm{v})$ peptone, $1.34 \%(\mathrm{w} / \mathrm{v})$ yeast nitrogen base without amino acids, $0.00004 \%(\mathrm{w} / \mathrm{v})$ biotin, $1 \%(\mathrm{v} / \mathrm{v})$ methanol, and $0.1 \mathrm{M}$ phosphate buffer at $\mathrm{pH} 6.0,7.0$, or 8.0) containing $0.04 \%(\mathrm{w} / \mathrm{v})$ histidine and $3 \%(\mathrm{v} / \mathrm{v})$ DMSO at 20 or $30^{\circ} \mathrm{C}$ from an initial $\mathrm{OD}_{600}$ of 1 . The procedure used for P. pastoris culture was described previously [29]. After a 20,40, or 60 hour induction, cells were harvested at 4,000 $\mathrm{g}$ for $15 \mathrm{~min}$, washed once with ice cold water, and frozen or immediately used for membrane preparation.

\section{Large scale culture for $\mathrm{P}$. pastoris}

Single $P$. pastoris colonies from high expressing clones were selected on YPD plates containing $0.1 \mathrm{mg} / \mathrm{ml}$ G418. Cells from a single colony were used to inoculate $200 \mathrm{ml}$ of BMGY medium. The culture was grown overnight at $30^{\circ} \mathrm{C}$ to an $\mathrm{OD}_{600}$ of 2-6. A total of $500 \mathrm{ml}$ of BMGY was inoculated with $100 \mathrm{ml}$ of the starter culture and grown for $4 \mathrm{hr}$ to an $\mathrm{OD}_{600}$ of 5-10. The cells were spun down at 4,000 $\mathrm{g}$ for $15 \mathrm{~min}$, the cell pellet was washed with double distilled water, and then the cells were spun down. The cell pellet was resuspended in 500 $\mathrm{ml}$ BMMY to an $\mathrm{OD}_{600}$ of 1 . The culture was incubated for 1-4 days at $20^{\circ} \mathrm{C}$ with shaking at $250 \mathrm{rpm}$, and then $25 \mathrm{ml}$ of $20 \%$ methanol was added to the cell culture to maintain a final methanol concentration of $1 \%$ every day until the end of the culture period.

\section{Small scale culture for Sf9 insect cells}

Sf9 insect cells were maintained in IP-41-based medium or ESF-921 medium each containing 3.5, 5 or $7 \%$ heatinactivated fetal bovine serum. Preparation of culture medium was described previously [65]. Briefly, complete culture media were mixed at a ratio of $70 \%$ IPL- 41 medium to $30 \%$ SF900II serum free medium and supplemented with $0.1 \%$ pluronic F-68 and 3.5 or $7 \%$ FBS. The small scale culture was carried out to transfer to large scale culture using a wave bioreactor (GE Healthcare). Sf9 insect cells were cultured in Erlenmeyer flasks with the $125 \mathrm{rpm}$ at $27^{\circ} \mathrm{C}$ culture conditions and passaged every 3 or 4 days.

\section{Large scale culture for Sf9 insect cells}

Sf9 insect cells were prepared at a density of $1.0 \times 10^{6}$ cells/ml and suspended in $5 \mathrm{~L}$ of the IPL-41/SF900 II complex media or ESF921 insect media. Media containing Sf9 insect cells were transferred into the CELLBAG $22 \mathrm{~L} / \mathrm{O}$ (GE Healthcare) [66,67] and cultured for 4 days with the following culture conditions: $20 \mathrm{rpm}, 8.5^{\circ}$ of rocking angle, $30 \% \mathrm{O}_{2}, 0.25 \mathrm{~L} / \mathrm{min}$ of air flow rate, and $27^{\circ} \mathrm{C}$. After 4 days, 200 300 $\mathrm{ml}$ of baculovirus stock 
(approximate multiplicity of infection $($ M.O.I) $=2$ ) and $700 \sim 800 \mathrm{ml}$ of IPL-41/SF900 II complex media were transferred into the CELLBAG (final culture volume $=6$ L) and infected for 2 days under the following infection conditions: $22 \mathrm{rpm}, 8.5^{\circ}$ of rocking angle, $50 \% \mathrm{O}_{2}$, air flow rate, $0.25 \mathrm{~L} / \mathrm{min}$, and $27^{\circ} \mathrm{C}$. Two days later, a fraction of the cells was harvested for the binding assay and the remaining cells were centrifuged at $6,000 \times$ g for 10 min and harvested. The cell pellet was washed with $250 \mathrm{ml}$ of Phosphate Buffered Saline without calcium chloride and magnesium chloride $(\operatorname{PBS}(-))$ and resuspended with $100 \mathrm{ml}$ of $\mathrm{PBS}(-)$ containing a protease inhibitor cocktail tablet (Roche). Cells were quick frozen in liquid nitrogen and stored at $-80^{\circ} \mathrm{C}$.

\section{Preparation of the cell membrane}

The preparation of cell membranes from $P$. pastoris was performed at $4^{\circ} \mathrm{C}$ or on ice. Harvested cells $(1 \mathrm{~g}$ of wet weight) were suspended in $4 \mathrm{ml}$ of lysis buffer $(50 \mathrm{mM}$ sodium phosphate buffer, $\mathrm{pH} 7.4,100 \mathrm{mM} \mathrm{NaCl}, 5 \%$ (v/v) glycerol, and $2 \mathrm{mM}$ EDTA) containing a cocktail of protease inhibitors (1 tablet/100 ml lysis buffer). After the addition of $0.5 \mathrm{~mm}$ glass beads to the cell suspension, yeast cells were disrupted by vortexing at $4^{\circ} \mathrm{C}$ for $2 \mathrm{hr}$. Lysis efficiency was evaluated using a light microscope and was usually more than $80 \%$. Intact cells and cell debris were separated from the membrane suspension by low speed centrifugation $(3,000 \mathrm{~g}, 5 \mathrm{~min}$ and $4^{\circ} \mathrm{C}$ ). Membranes were snap-frozen in liquid nitrogen and stored at $-80^{\circ} \mathrm{C}$.

For the preparation of membranes from insect cells, Sf9 insect cells were centrifuged at 1,500 g for $10 \mathrm{~min}$ at $4{ }^{\circ} \mathrm{C}$. The pellet was washed with $\operatorname{PBS}(-)$, then resuspended in $100 \mathrm{ml}$ of hypotonic buffer containing $10 \mathrm{mM}$ HEPES at $\mathrm{pH}$ 7.5, $20 \mathrm{mM}$ potassium chloride, $10 \mathrm{mM} \mathrm{MgCl}_{2}$, and protease inhibitor cocktail, followed by Dounce homogenization to resuspend the membranes. Insect cell membranes were centrifuged at $100,000 \mathrm{~g}$ for $30 \mathrm{~min}$ and the pellets were resuspended in $10 \mathrm{mM}$ HEPES at $\mathrm{pH} 7.5,10 \mathrm{mM}$ magnesium chloride, $20 \mathrm{mM}$ potassium chloride, and $40 \%$ glycerol, and then flash-frozen in liquid nitrogen and stored at $-80^{\circ} \mathrm{C}$ until further use.

\section{Solubilization and purification of CHRM2}

Membrane suspensions of the CHRM2 were solubilized in solubilization buffer containing $20 \mathrm{mM}$ HEPES, $\mathrm{pH}$ 7.0, $500 \mathrm{mM} \mathrm{NaCl}, 20 \%$ glycerol, $1 \%$ n-dodecyl- $\beta$-D-maltopyranoside (DDM) (Affymetrix), 0.2\% cholesterol hemisuccinate (CHS) (Sigma), and protease inhibitor cocktail at $4^{\circ} \mathrm{C}$ for $2 \mathrm{hr}$. The insoluble materials were pelleted by ultracentrifugation at 200,000 g for $1 \mathrm{hr}$ at $4^{\circ} \mathrm{C}$. TALON metal affinity resin (Clontech) equilibrated in purification buffer (20 mM HEPES, pH 7.0, 800 mM NaCl, 10\% glycerol, 0.05\% DDM, 0.01\% CHS and protease inhibitor cocktail) was added to the solubilized membranes and incubated for $2 \mathrm{hr}$ at $4^{\circ} \mathrm{C}$. CHRM2 protein was eluted with purification buffer containing $250 \mathrm{mM}$ imidazole. ConA agarose (Seikagaku Corporation) equilibrated in purification buffer was added to the TALON-purified $\mathrm{CHRM} 2$ and incubated overnight at $4^{\circ} \mathrm{C}$. The ConA agarose flow-through fraction was harvested. The purified CHRM2 protein was subjected to SDS-PAGE, CBB staining, and a specific binding assay.

\section{Radioligand binding assay}

Binding assays were conducted in polystyrol tubes using assay buffer (20 mM potassium phosphate buffer). GF/F glass filters were presoaked in $200 \mathrm{ml}$ of $0.3 \%(\mathrm{v} / \mathrm{v})$ polyethyleneimine. All experiments were performed in duplicate in a total volume of $200 \mu \mathrm{l}$. Membrane proteins were quantified using the bicinchoninic acid (BCA) method (Thermo Fisher Scientific) with bovine serum albumin as a standard. Membrane proteins $(2.5 \mu \mathrm{g})$ were incubated for $30 \mathrm{~min}$ at $25^{\circ} \mathrm{C}$ in $200 \mu \mathrm{l}$ of assay buffer containing $1.5 \mathrm{nM}\left[{ }^{3} \mathrm{H}\right] \mathrm{QNB}$ for single point binding assays at saturating radioligand concentrations. Non-specific binding was obtained by incubation in the presence of an excess of the non-radioactive ligand, namely in $100 \mu \mathrm{M}$ atropine. Bound and free ligands were separated by rapid vacuum filtration over GF/F filters. Filtration was carried out with a Brandel cell harvester at room temperature. Filters were washed three times with ice cold water. The retained radioactivity was measured on an LCS-5100 liquid scintillation counter (ALOKA).

\section{Experimental design and Statistical evaluation}

Experiments in each group were repeated independently at least 3 times. The $\mathrm{Kd}$ and Bmax values were estimated using the saturation binding assay and Scatchard plots. Data are presented as the means \pm standard deviation (S.D.).

\section{Additional material}

Additional File 1: Fig. S1. Morphological change of Sf9 insect cell by baculovirus infection. Healthy, uninfected Sf9 insect cells (A) and cells 2 days after baculovirus infection (B) were mounted on slide glass and observed under bright-field microscopy. (×40) (Scale bar, $10 \mu \mathrm{m}$.

Images were independently observed 3 times and representative images are shown.

\section{Acknowledgements}

We thank Chiho Fukui for office administration tasks. This work was supported in part by a grant from the ERATO Iwata human receptor crystallography project from the Japan Science and Technology Agency (JST) to S.I.; by a grant from the Takeda Science Foundation, by a grant from The Sumitomo Foundation, by a grant from Ichiro Kanehara Foundation, by 
a grant form The Mochida Memorial Foundation for Medical and Pharmaceutical Research and by a Research Fellowship from the Uehara Medical Foundation to T.K.; by a Grant-in-Aid for Scientific Research (B) (20370035 to T.K., 21370043 to T.S); and by a Challenging Exploratory Research (22659059 to T.K.).

\section{Author details}

${ }^{1}$ Iwata Human Receptor Crystallography project, ERATO, JST, Konoe-cho, Yoshida, Sakyo-ku, Kyoto 606-8501, Japan. Department of Medical Chemistry, Kyoto University Faculty of Medicine, Konoe-cho, Yoshida, Sakyoku, Kyoto 606-8501, Japan. ${ }^{3}$ Department of Applied Biological Chemistry, Graduate School of Agricultural and Life Sciences, The University of Tokyo, Bunkyo-ku, Tokyo 113-8657, Japan. ${ }^{4}$ Institute for Biomolecular Science, Faculty of Science, Gakushuin University, 1-5-1 Mejiro, Toshima-ku, Tokyo 171-8588, Japan. ${ }^{5}$ RIKEN Genomic Science Center, 1-7-22 Suehiro-cho, Tsurumi, Yokohama 230-0045, Japan. ${ }^{6}$ Membrane Protein Crystallography Group, Division of Molecular Biosciences, Imperial College London, SW7 2AZ, UK.

\section{Authors' contributions}

HA, TU and TS carried out the optimization of Sf9 expression conditions. TY$\mathrm{K}, \mathrm{KI}, \mathrm{TS}$ and TN carried out the optimization of $P$. pastoris expression conditions. MS and HT performed the ligand binding assays. NN and TM contributed to the data analysis and interpretation. TH constructed the baculovirus vector carrying the CHRM2 gene. SI and TK designed the study and reviewed the final manuscript. All authors read and approved the final manuscript.

\section{Competing interests}

The authors declare that they have no competing interests.

Received: 22 December 2010 Accepted: 22 April 2011

Published: 22 April 2011

\section{References}

1. Hopkins AL, Groom CR: The druggable genome. Nat Rev Drug Discov 2002, 1:727-730.

2. Klabunde T, Hessler G: Drug design strategies for targeting G-proteincoupled receptors. Chembiochem 2002, 3:928-944.

3. Alkhalfioui F, Magnin T, Wagner R: From purified GPCRs to drug discovery: the promise of protein-based methodologies. Current opinion in pharmacology 2009, 9:629-635.

4. Palczewski K, Kumasaka T, Hori T, Behnke CA, Motoshima H, Fox BA, Le Trong I, Teller DC, Okada T, Stenkamp RE, et al: Crystal structure of rhodopsin: A G protein-coupled receptor. Science 2000, 289:739-745.

5. Park JH, Scheerer P, Hofmann KP, Choe HW, Ernst OP: Crystal structure of the ligand-free G-protein-coupled receptor opsin. Nature 2008, 454:183-187.

6. Murakami M, Kouyama T: Crystal structure of squid rhodopsin. Nature 2008, 453:363-367.

7. Shimamura T, Hiraki K, Takahashi N, Hori T, Ago H, Masuda K, Takio K, Ishiguro M, Miyano M: Crystal structure of squid rhodopsin with intracellularly extended cytoplasmic region. J Biol Chem 2008, 283:17753-17756.

8. Haga K, Kameyama K, Haga T, Kikkawa U, Shiozaki K, Uchiyama H: Phosphorylation of human $\mathrm{m} 1$ muscarinic acetylcholine receptors by $\mathrm{G}$ protein-coupled receptor kinase 2 and protein kinase C. J Biol Chem 1996, 271:2776-2782.

9. Hayashi MK, Haga T: Palmitoylation of muscarinic acetylcholine receptor $\mathrm{m} 2$ subtypes: reduction in their ability to activate $\mathrm{G}$ proteins by mutation of a putative palmitoylation site, cysteine 457 , in the carboxylterminal tail. Arch Biochem Biophys 1997, 340:376-382.

10. Furukawa H, Hamada T, Hayashi MK, Haga T, Muto Y, Hirota H, Yokoyama S, Nagasawa K, Ishiguro M: Conformation of ligands bound to the muscarinic acetylcholine receptor. Molecular pharmacology 2002, 62:778-787.

11. Perret BG, Wagner R, Lecat S, Brillet K, Rabut G, Bucher B, Pattus F: Expression of EGFP-amino-tagged human mu opioid receptor in Drosophila Schneider 2 cells: a potential expression system for largescale production of G-protein coupled receptors. Protein expression and purification 2003, 31:123-132.
12. Takeda S, Yamamoto A, Okada T, Matsumura E, Nose E, Kogure K, Kojima S, Haga T: Identification of surrogate ligands for orphan $G$ protein-coupled receptors. Life Sci 2003, 74:367-377.

13. Warne T, Chirnside J, Schertler GF: Expression and purification of truncated, non-glycosylated turkey beta-adrenergic receptors for crystallization. Biochim Biophys Acta 2003, 1610:133-140.

14. Akermoun M, Koglin M, Zvalova-looss D, Folschweiller N, Dowell SJ, Gearing KL: Characterization of 16 human G protein-coupled receptors expressed in baculovirus-infected insect cells. Protein expression and purification 2005, 44:65-74.

15. Brillet K, Perret BG, Klein V, Pattus F, Wagner R: Using EGFP fusions to monitor the functional expression of GPCRs in the Drosophila Schneider 2 cells. Cytotechnology 2008, 57:101-109.

16. Brillet K, Pereira CA, Wagner R: Expression of membrane proteins in Drosophila Melanogaster S2 cells: Production and analysis of a EGFPfused $\mathrm{G}$ protein-coupled receptor as a model. Methods in molecular biology 2010, 601:119-133.

17. Furukawa $H$, Haga $T$ : Expression of functional $M 2$ muscarinic acetylcholine receptor in Escherichia coli. J Biochem 2000, 127:151-161.

18. Ichiyama S, Oka Y, Haga K, Kojima S, Tateishi Y, Shirakawa M, Haga T: The structure of the third intracellular loop of the muscarinic acetylcholine receptor M2 subtype. FEBS Lett 2006, 580:23-26.

19. Harding PJ, Attrill H, Ross S, Koeppe JR, Kapanidis AN, Watts A: Neurotensin receptor type 1: Escherichia coli expression, purification, characterization and biophysical study. Biochem Soc Trans 2007, 35:760-763.

20. Michalke K, Graviere ME, Huyghe C, Vincentelli R, Wagner R, Pattus F, Schroeder K, Oschmann J, Rudolph R, Cambillau C, Desmyter A: Mammalian G-protein-coupled receptor expression in Escherichia coli: I. High-throughput large-scale production as inclusion bodies. Anal Biochem 2009, 386:147-155.

21. Michalke K, Huyghe C, Lichiere J, Graviere ME, Siponen M, Sciara G, Lepaul I, Wagner R, Magg C, Rudolph R, et al: Mammalian G protein-coupled receptor expression in Escherichia coli: II. Refolding and biophysical characterization of mouse cannabinoid receptor 1 and human parathyroid hormone receptor 1. Analytical biochemistry 2010, 401:74-80.

22. Niebauer RT, Robinson AS: Exceptional total and functional yields of the human adenosine (A2a) receptor expressed in the yeast Saccharomyces cerevisiae. Protein expression and purification 2006, 46:204-211.

23. Lee BK, Jung KS, Son C, Kim H, VerBerkmoes NC, Arshava B, Naider F, Becker JM: Affinity purification and characterization of a G-protein coupled receptor, Saccharomyces cerevisiae Ste2p. Protein expression and purification 2007, 56:62-71.

24. Andre N, Cherouati N, Prual C, Steffan T, Zeder-Lutz G, Magnin T, Pattus F, Michel H, Wagner R, Reinhart C: Enhancing functional production of $G$ protein-coupled receptors in Pichia pastoris to levels required for structural studies via a single expression screen. Protein Sci 2006, 15:1115-1126.

25. Zeder-Lutz G, Cherouati N, Reinhart C, Pattus F, Wagner R: Dot-blot immunodetection as a versatile and high-throughput assay to evaluate recombinant GPCRs produced in the yeast Pichia pastoris. Protein expression and purification 2006, 50:118-127.

26. Zhang R, Kim TK, Qiao ZH, Cai J, Pierce WM, Song ZH: Biochemical and mass spectrometric characterization of the human CB2 cannabinoid receptor expressed in Pichia pastoris-importance of correct processing of the N-terminus. Protein expression and purification 2007, 55:225-235.

27. Singh S, Gras A, Fiez-Vandal C, Ruprecht J, Rana R, Martinez M, Strange PG, Wagner R, Byrne B: Large-scale functional expression of WT and truncated human adenosine A2A receptor in Pichia pastoris bioreactor cultures. Microbial cell factories 2008, 7:28.

28. Magnin T, Fiez-Vandal C, Potier N, Coquard A, Leray I, Steffan T, Logez C, Alkhalfioui F, Pattus F, Wagner R: A novel, generic and effective method for the rapid purification of $\mathrm{G}$ protein-coupled receptors. Protein expression and purification 2009, 64:1-7.

29. Yurugi-Kobayashi T, Asada H, Shiroishi M, Shimamura T, Funamoto $\mathrm{S}$, Katsuta N, Ito K, Sugawara T, Tokuda N, Tsujimoto H, et al: Comparison of functional non-glycosylated GPCRs expression in Pichia pastoris. Biochem Biophys Res Commun 2009, 380:271-276.

30. Singh S, Hedley D, Kara E, Gras A, Iwata S, Ruprecht J, Strange PG, Byrne B: A purified C-terminally truncated human adenosine $A(2 A)$ receptor construct is functionally stable and degradation resistant. Protein expression and purification 2010, 74:80-87. 
31. Chelikani P, Reeves PJ, Rajbhandary UL, Khorana HG: The synthesis and high-level expression of a beta2-adrenergic receptor gene in a tetracycline-inducible stable mammalian cell line. Protein Sci 2006, 15:1433-1440.

32. Hassaine G, Wagner R, Kempf J, Cherouati N, Hassaine N, Prual C, Andre N, Reinhart C, Pattus F, Lundstrom K: Semliki Forest virus vectors for overexpression of $101 \mathrm{G}$ protein-coupled receptors in mammalian host cells. Protein expression and purification 2006, 45:343-351.

33. Bunni MA, Morinelli TA, Raymond JR, Garnovskaya MN: Identification of functional bradykinin $B(2)$ receptors endogenously expressed in HEK293 cells. Biochem Pharmacol 2009, 77:269-276.

34. Jiang C, Chen G, Zeng X, Ouyang K, Hu Y: Generation of a bioactive neuropeptide in a cell-free system. Analytical biochemistry 2003, 316:34-40.

35. Ishihara G, Goto M, Saeki M, Ito K, Hori T, Kigawa T, Shirouzu M, Yokoyama S: Expression of $\mathrm{G}$ protein coupled receptors in a cell-free translational system using detergents and thioredoxin-fusion vectors. Protein expression and purification 2005, 41:27-37.

36. Klammt C, Schwarz D, Eifler N, Engel A, Piehler J, Haase W, Hahn S, Dotsch V, Bernhard F: Cell-free production of G protein-coupled receptors for functional and structural studies. Journal of structural biology 2007, 158:482-493

37. Kaiser L, Graveland-Bikker J, Steuerwald D, Vanberghem M, Herlihy K, Zhang S: Efficient cell-free production of olfactory receptors: detergent optimization, structure, and ligand binding analyses. Proc Natl Acad Sci USA 2008, 105:15726-15731.

38. Kamonchanok S, Balog Cl, van der Does AM, Booth R, de Grip WJ, Deelder AM, Bakker RA, Leurs R, Hensbergen PJ: GPCR proteomics: mass spectrometric and functional analysis of histamine $\mathrm{H} 1$ receptor after baculovirus-driven and in vitro cell free expression. Journal of proteome research 2008, 7:621-629.

39. Junge F, Luh LM, Proverbio D, Schafer B, Abele R, Beyermann M, Dotsch V, Bernhard F: Modulation of G-protein coupled receptor sample quality by modified cell-free expression protocols: a case study of the human endothelin A receptor. Journal of structural biology 2010, 172:94-106.

40. Cherezov V, Rosenbaum DM, Hanson MA, Rasmussen SG, Thian FS, Kobilka TS, Choi HJ, Kuhn P, Weis WI, Kobilka BK, Stevens RC: Highresolution crystal structure of an engineered human beta2-adrenergic $\mathrm{G}$ protein-coupled receptor. Science 2007, 318:1258-1265.

41. Rasmussen SG, Choi HJ, Rosenbaum DM, Kobilka TS, Thian FS, Edwards PC, Burghammer M, Ratnala VR, Sanishvili R, Fischetti RF, et al: Crystal structure of the human beta2 adrenergic G-protein-coupled receptor. Nature 2007, 450:383-387

42. Jaakola VP, Griffith MT, Hanson MA, Cherezov V, Chien EY, Lane JR, ljzerman AP, Stevens RC: The 2.6 angstrom crystal structure of a human A2A adenosine receptor bound to an antagonist. Science 2008, 322:1211-1217.

43. Wu B, Chien EY, Mol CD, Fenalti G, Liu W, Katritch V, Abagyan R, Brooun A, Wells $P, B i$ FC, et al: Structures of the CXCR4 chemokine GPCR with smallmolecule and cyclic peptide antagonists. Science 2010, 330:1066-1071.

44. Chien EY, Liu W, Zhao Q, Katritch V, Han GW, Hanson MA, Shi L, Newman AH, Javitch JA, Cherezov V, Stevens RC: Structure of the human dopamine $\mathrm{D} 3$ receptor in complex with a D2/D3 selective antagonist. Science 2010, 330:1091-1095.

45. Wess J, Bonner Tl, Dorje F, Brann MR: Delineation of muscarinic receptor domains conferring selectivity of coupling to guanine nucleotidebinding proteins and second messengers. Molecular pharmacology 1990, 38:517-523.

46. Wess J, Bonner TI, Brann MR: Chimeric m2/m3 muscarinic receptors: role of carboxyl terminal receptor domains in selectivity of ligand binding and coupling to phosphoinositide hydrolysis. Molecular pharmacology 1990, 38:872-877.

47. Bonner Tl, Buckley NJ, Young AC, Brann MR: Identification of a family of muscarinic acetylcholine receptor genes. Science 1987, 237:527-532.

48. Peralta EG, Ashkenazi A, Winslow JW, Smith DH, Ramachandran J, Capon DJ: Distinct primary structures, ligand-binding properties and tissue-specific expression of four human muscarinic acetylcholine receptors. Embo J 1987, 6:3923-3929.

49. Bonner TI, Young AC, Brann MR, Buckley NJ: Cloning and expression of the human and rat $\mathrm{m} 5$ muscarinic acetylcholine receptor genes. Neuron $1988,1: 403-410$
50. Bonner TI: New subtypes of muscarinic acetylcholine receptors. Trends Pharmacol Sci 1989, Suppl:: 11-15.

51. Bonner TI: The molecular basis of muscarinic receptor diversity. Trends Neurosci 1989, 12:148-151.

52. Hayashi MK, Haga T: Purification and functional reconstitution with GTPbinding regulatory proteins of hexahistidine-tagged muscarinic acetylcholine receptors (m2 subtype). J Biochem 1996, 120:1232-1238.

53. Long SB, Campbell EB, Mackinnon R: Crystal structure of a mammalian voltage-dependent Shaker family K+ channel. Science 2005, 309:897-903.

54. Brejc K, van Dijk WJ, Klaassen RV, Schuurmans M, van Der Oost J, Smit AB, Sixma TK: Crystal structure of an ACh-binding protein reveals the ligandbinding domain of nicotinic receptors. Nature 2001, 411:269-276

55. Warne T, Serrano-Vega MJ, Baker JG, Moukhametzianov R, Edwards PC, Henderson R, Leslie AG, Tate CG, Schertler GF: Structure of a beta1adrenergic G-protein-coupled receptor. Nature 2008, 454:486-491.

56. Long SB, Tao X, Campbell EB, MacKinnon R: Atomic structure of a voltagedependent $\mathrm{K}+$ channel in a lipid membrane-like environment. Nature 2007, 450:376-382

57. Tao X, Mackinnon R: Functional analysis of Kv1.2 and paddle chimera Kv channels in planar lipid bilayers. Journal of molecular biology 2008, 382:24-33

58. Heitz F, Nay $C$, Guenet $C$ : Expression of functional human muscarinic $M 2$ receptors in different insect cell lines. Journal of receptor and signal transduction research 1997, 17:305-317.

59. Gotoh T, Miyazaki Y, Kikuchi K, Bentley WE: Investigation of sequential behavior of carboxyl protease and cysteine protease activities in virusinfected Sf-9 insect cell culture by inhibition assay. Applied microbiology and biotechnology 2001, 56:742-749.

60. Hu YC, Bentley WE: Enhancing yield of infectious Bursal disease virus structural proteins in baculovirus expression systems: focus on media, protease inhibitors, and dissolved oxygen. Biotechnology progress 1999, 15:1065-1071

61. Hanson MA, Brooun A, Baker KA, Jaakola VP, Roth C, Chien EY, Alexandrov A, Velasquez J, Davis L, Griffith M, et al: Profiling of membrane protein variants in a baculovirus system by coupling cell-surface detection with small-scale parallel expression. Protein expression and purification 2007, 56:85-92.

62. Guarna MM, Lesnicki GJ, Tam BM, Robinson J, Radziminski CZ, Hasenwinkle D, Boraston A, Jervis E, MacGillivray RT, Turner RF, Kilburn DG On-line monitoring and control of methanol concentration in shakeflask cultures of Pichia pastoris. Biotechnology and bioengineering 1997, 56:279-286.

63. Scorer CA, Clare JJ, McCombie WR, Romanos MA, Sreekrishna K: Rapid selection using G418 of high copy number transformants of Pichia pastoris for high-level foreign gene expression. Biotechnology (N Y) 1994, 12:181-184.

64. Weiss HM, Haase W, Michel H, Reilander H: Comparative biochemical and pharmacological characterization of the mouse 5HT5A 5hydroxytryptamine receptor and the human beta2-adrenergic receptor produced in the methylotrophic yeast Pichia pastoris. Biochem J 1998, 330(Pt 3):1137-1147.

65. Nakamura F, Kato M, Kameyama K, Nukada T, Haga T, Kato H, Takenawa T, Kikkawa U: Characterization of Gq family G proteins GL1 alpha (G14 alpha), GL2 alpha (G11 alpha), and Gq alpha expressed in the baculovirus-insect cell system. J Biol Chem 1995, 270:6246-6253.

66. Weber W, Weber E, Geisse S, Memmert K: Optimisation of protein expression and establishment of the Wave Bioreactor for Baculovirus/ insect cell culture. Cytotechnology 2002, 38:77-85.

67. Kadwell SH, Hardwicke PI: Production of baculovirus-expressed recombinant proteins in wave bioreactors. Methods Mol Biol 2007, 388:247-266.

doi:10.1186/1475-2859-10-24

Cite this article as: Asada et al.: Evaluation of the Pichia pastoris expression system for the production of GPCRs for structural analysis. Microbial Cell Factories 2011 10:24 